D. Gabor, professor of applied electron physics in the Imperial College of Science and Technology, London, and Dr. D. Jones, of the Department of Electrical Engineering in the Imperial College, for the development of an electron interference microscope; $£ 8,100$ to Dr. H. H. Hopkins, reader in optics, Department of Physics, Imperial College of Science and Technology, London, for the development of methods of drawing and coating fine glass fibres, and their alignment in ordered bundles for the transmission of optical images; $£ 3,000$, in supplement of a previous grant, to Prof. R. O. Redman, professor of astrophysics in the University of Cambridge, for the con struction and testing of a thin astronomical mirror of plate glass and of a new type of support system;

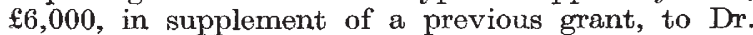
C. N. Smyth, of University College Hospital Medical School, London, and Mr. F. Y. Poynton, of Northampton College of Advanced Technology, London, for the construction of an ultrasonic microscope.

The Paul Instrument Fund Committee, composed of representatives of the Royal Society, the Physical Society, the Institute of Physics and the Institution of Electrical Engineers, was set up in 1945 "to receive applications from British subjects who are research workers in Great Britain for grants for the design, construction and maintenance of novel, unusual or much improved types of physical instruments and apparatus for investigations in pure or applied physical science".

\section{Commonwealth Scholarship Commission in the United Kingdom}

THE following have been appointed members of the Commonwealth Scholarship Commission in the United Kingdom by the Secretary of State for Commonwealth Relations, Lord Home, and the Secretary of State for the Colonies, Mr. Ian Macleod : The Earl of Scarbrough, the Lord Chamberlain (chairman); Dr. R. S. Aitken, vice-chancellor of the University of Birmingham; Sir David Anderson, recently director of the Royal Technical College, Glasgow ; Sir Eric Ashby, master of Clare College, Cambridge ; Sir Eric Coates, Finance Minister of the Governor General of India's Executive Council, 1946 ; Lord Geddes of Epsom, member of the London Transport Executive; Sir Hector Hetherington, principal and vice-chancellor of the University of Glasgow ; Sir Francis Hill, chairman, General Purposes Committee of the Association of Municipal Corporations ; Sir Cyril Hinshelwood, Dr. Lee's professor of chemistry in the University of Oxford, and president of the Royal Society ; Sir Douglas Logan, principal of the University of London; Lady Ogilvie, principal of St. Anne's College, Oxford ; Sir Julian Pode, managing director of the Steel Company of Wales, and chairman of the Managing Committee of the United Kingdom for the Athlone Fellowships scheme ; Sir Paul Sinker, director general of the British Council, and First Civil Service Commissioner, 1951-54; Dr. R. W. West, principal of Battersea College of Technology. The Commission has been set up under the Commonwealth Scholarships Act recently passed by Parliament to administer the Commonwealth Scholarship and Fellowship Plan in Great Britain.

\section{A Hundred Years of Optics}

IN 1860 John Henry Dallmeyer took out a patent and issued his first Triple Achromatic lens, marking the foundation to the House of Dallmeyer. J. H. Dallmeyer was born in Westphalia in 1830 and went to Great Britain in 1851. He first set up a business designing and manufacturing lenses and optical instruments at 19 Bloomsbury Street, London. In 1861 he was elected a Fellow of the Royal Astronomical Society, and four years later invented the Dallmeyer Rectilinear lens. Improvements in optical technology brought about the series of $f / 3, f / 4$ and f/6 Patent Portrait lenses. The management of the business gradually devolved upon Thomas Rudolph Dallmeyer, who, like his father, possessed a wealth of knowledge in optics. In 1891 the first practically useful telephoto lens was designed and issued by him, only to be followed by the Adon telephoto lens in 1892. One of the earliest treatises on the use of telephoto lenses was to his credit, and "Telephotography" was published in 1899. T. R. Dallmeyer died in 1906, and it was only due to the fact that a private limited company had been formed in 1892 that the business remained established. Later developments included the pioneering of the first fixed-separation telephoto lens, the inventions of the Dallon Fixed-separation Telephoto lens and the Pentac anastigmat lens. It was the Pentac lens that created new standards in large-aperture anastigmal lenses, and which was used during the Second World War for aerial reconnaissance both by day and night. It is with much eredit to its pioneers that the House of Dallmeyer celebrates its centenary.

\section{Public Health Laboratory Service in Britain}

The Public Health Laboratory Service Bill, which received its second reading in the House of Lords on February 4, transfers the administration of the Public Health Laboratory Service in Britain from the Medical Research Council to a new Public Health Laboratory Service Board appointed by the Minister of Health and subject to his directions. The Board will consist of a chairman and nine other members, one of whom must be medically qualified; two members will be appointed after consultation with the Medical Research Council, two must have had experience as bacteriologists, two will be medical officers of health of local authorities, and two with administrative experience. Clauses in the Bill transfer the staff of the Public Health Laboratory Service from the Medical Research Council to the new Board, and property held for the Public Health Laboratory Service is transferred to the Minister of Health. In introducing the Bill, the Minister for Science, Lord Hailsham, explained that the Service had its origin in an emergency service created shortly before the Second World War at the request of the Committee of Imperial Defence, in order to provide a defence against possible enemy use of bacteriological warfare and against any major outbreaks of epidemic diseases arising from war-time conditions. In the event it was never used to deal with any such major emergency, but it proved a very valuable aid to the medical officers of health in their ordinary work, in view of the inadequacy of the arrangements for bacteriological work for public health purposes. Unlike the Hospital Laboratory Services, it was organized on a national and not on a regional or hospital basis, and consists at present of the Central Public Health Laboratory, eight regional and 51 area laboratories, with several special reference libraries ; of the staff of about 1,068, 126 are medically qualified. $\mathfrak{1 , 2 1 2 , 0 0 0}$ was provided for the cost of 